\title{
Statistical Analysis and Thermodynamic Equilibrium Modelling for Chemical Composition of Groundwater and Spring Water at Jeju Island, South Korea
}

\author{
Byeong Dae Lee ${ }^{1}$, Chan Ho Jeong ${ }^{2, *}$, Yong Cheon Lee ${ }^{2, *(\mathbb{D})}$, Yu Jin Lee ${ }^{2}$, Jae Ha Yang ${ }^{3}$, \\ Chang Oh Choo ${ }^{4}$, Hyeon Woo Jang ${ }^{2}$, Yong Hwa $\mathrm{Oh}^{1}$ and Jin Woo Hong ${ }^{2}$ \\ 1 Groundwater Research Center, Korea Institute of Geoscience and Mineral Resources, Daejeon 34132, Korea; \\ blee@kigam.re.kr (B.D.L.); yonghwa.oh@gmail.com (Y.H.O.) \\ 2 Department of Construction and Disaster Prevention Engineering, Daejeon University, Daejeon 34520, Korea; \\ geoabby20@naver.com (Y.J.L.); jhwtime@gmail.com (H.W.J.); jinwoo_hong@naver.com (J.W.H.) \\ 3 EGI Consulting Co., Incheon 22698, Korea; egiconsl@gmail.com \\ 4 Department of Earth and Environmental Sciences, Andong National University, Andong 36729, Korea; \\ mineralogy@hanmail.net \\ * Correspondence: chjeong@dju.kr (C.H.J.); dydcjs159@naver.com (Y.C.L.); Tel.: +82-42-280-2573 (C.H.J.); \\ +82-10-2908-0057 (Y.C.L.)
}

Received: 3 February 2020; Accepted: 7 March 2020; Published: 11 March 2020

\begin{abstract}
The purpose of this study is to delineate the main contributions controlling the chemical composition of groundwater and spring water samples at Jeju Island, South Korea. Groundwater and spring water can be grouped as three chemical types: Fresh water $\left(\mathrm{Ca}, \mathrm{Na}-\mathrm{HCO}_{3}\right)$, sea water mixing $\left(\mathrm{Na}-\mathrm{Cl}, \mathrm{SO}_{4}\right)$ and contamination $\left(\mathrm{Ca}-\mathrm{NO}_{3}, \mathrm{Cl}\right)$. By factor analysis, three factors can explain about $87 \%$ of chemical variances: Factor $1\left(\mathrm{Na}^{+}\right.$and $\left.\mathrm{Cl}^{-}\right)$, factor $2\left(\mathrm{NO}_{3}{ }^{-}\right)$, and factors $3\left(\mathrm{HCO}_{3}{ }^{-}\right)$, which are regarded as indicative ions of sea water mixing, contamination and mineral-water interaction, respectively. Sea water intrusion in the southeastern area of Jeju Island is due to downward distribution of Seogwipo Formation, which plays a role as an aquiclude preventing sea water intrusion in other areas, under sea level at the southeastern coastal area. Nitrate contamination is likely to be affected by pollution sources, i.e., agricultural activities, horse farms and municipal sewage. Thermodynamic saturation index indicates that most of waters are undersaturated with respect to major minerals, which may result from insufficient reaction time within a permeable aquifer. The unsaturation state corresponds to low load scores of $\mathrm{Ca}, \mathrm{Mg}, \mathrm{Na}, \mathrm{K}$, and $\mathrm{SiO}_{2}$ in factor 3, which means a low contribution of mineral-water interaction.
\end{abstract}

Keywords: chemical composition; contamination; factor analysis; groundwater; kriging; sea water intrusion; spring water; saturation indices

\section{Introduction}

Jeju volcanic island is located at the margin of the southwestern part in Korean Peninsula (Figure 1a). Jeju Island, which has been known as an attractive natural reserve area and beautiful scene, was designated as world natural heritage at 2007 by United National Educational, Scientific and Cultural Organization (UNESCO). Tourists greatly increased from 5.8 million in 2008 to 15 million in 2019. For last 50 years, the population of Jeju Island has steadily increased from 358,085 in 1970 to 692,032 in 2018. Water demand has been persistently increased from 146 thousand ton in 2008 to 212.5 thousand ton in 2017 along with the increase of population and tourists [1,2].

Although the island has been known as having the heaviest amount of rainfall (av. $1700 \mathrm{~mm} /$ year) in Korean Peninsula during last several ten years, surface water resources are always insufficient 
due to the hydrogeological characteristic of highly porous volcanic rocks, where a large amount of rainfall rapidly infiltrates into a permeable underground layer. In the mountainous area of Jeju Island, available water resources are always lacked, while many spring waters yield along the coastal area. Hence, the spring water has been used as a drinking water for a long time before a deep groundwater development until the 1970s. However, spring water along coastal area had also a problem such as sea water mixing, which can cause inappropriate quality as a drinking water. After 1970s, although a lot of groundwaters have been developed as a main water resource including a drinking water, a rapid enlargement of potential contamination sources such as many leisure facilities including hotels and golf resorts, agricultural activities and horse farms that are mainly developed along a coastal line and in mid-mountain areas is threatening the quality of groundwater as a drinking water [3].

Previous geochemical and hydrogeological studies related with groundwater and spring water in Jeju Island have been carried out by several researchers. Koh et al. (2017) estimated the temporal trends from 1993 to 2012 about the concentrations of $\mathrm{NO}_{3}-\mathrm{N}$ and $\mathrm{Cl}$ from previous data of more than 3900 groundwater samples in Jeju Island by using the Mann-Kendall trend test and Sen's slope analysis, and also analyzed the groundwater contamination according to the change of land use for the period 1995-2009 [4]. All previous data of nitrate and chloride in groundwater of Jeju Island were collected from rectangle grids of $500 \mathrm{~m}$ by $500 \mathrm{~m}$, and these data were arranged in time series order and analyzed using Sen's method [5]. The results showed the upward trend of their concentrations from the early 1990s to the early 2000s. In particular, nitrate content has been increased in the low and mid-mountain areas in western and southern watersheds of the island.

The purpose of this study is to investigate the geological and other contributions controlling chemical composition of groundwater and spring water in Jeju Island by using statistical methods such as box-whisker diagram, correlation and factor analyses and thermodynamic equilibrium calculation. Correlation and factor analyses were applied to better explain the possible processes such as water-mineral interaction, anthropogenic inputs and sea water mixing as the origin of the chemical ions of groundwater and spring water. In particular, thermodynamic equilibrium modelling makes an attempt firstly to assess the saturation state of groundwater and spring water with respect to major minerals of Jeju volcanic rocks. Additionally, we applied firstly the kriging method to represent the degree of mineral-water interaction and hydrochemical evolution of groundwater and spring water based on the result of saturation index.

(a)

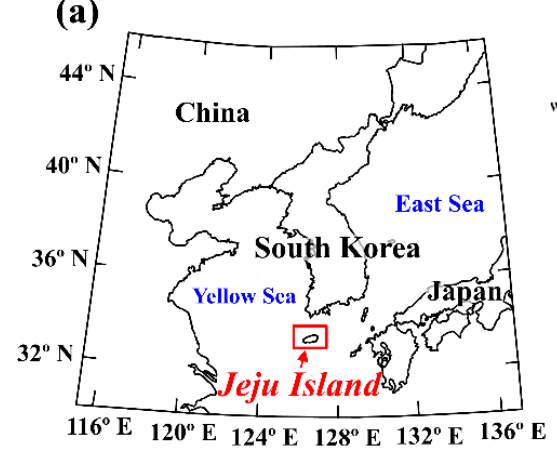

(b)

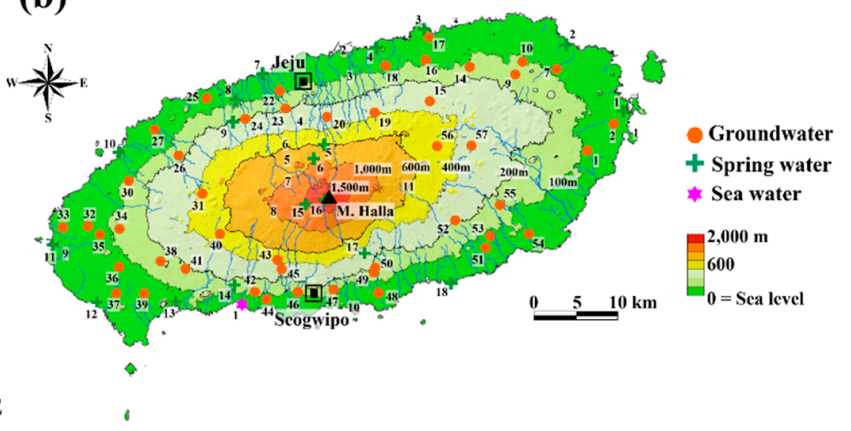

Figure 1. Location map of the study area (Jeju Island) in South Korea (a) and location map of groundwater, spring water and sea water samples collected in Jeju Island (b).

\section{Methods}

\subsection{Samples and In-Situ Measurement}

For this study, groundwater samples in Jeju Island were collected at 38 locations in July and at 47 locations in October, 2016, respectively. 18 spring water samples were also collected in July and October, 2016, respectively. 1 sea water was sampled at southern coastal line in July, 2016. The depth of groundwater wells ranges from -41 to $-450 \mathrm{~m}$. The wells are classified into 4 types in view point 
of purpose of use; 2 drinking water wells, 12 living water wells, 24 agricultural water wells and 9 observation wells. The location map of water samples is shown in Figure 1b. Measurements of $\mathrm{pH}$, oxidation-reduction potential (Eh), dissolved-oxygen content (DO), electrical conductivity (EC) of all water samples were made in situ while using portable instruments (HM-12P and CM-14P and RM-12P, DKK-TOA Co., Tokyo, Japan) 10-20 min after purging to achieve stable values in case of groundwater. Alkalinity, being expressed as $\mathrm{HCO}_{3}{ }^{-}$concentration, was quantified on-site by titration with $0.05 \mathrm{M}$ $\mathrm{HCl}$. All of the water samples were filtered through a $0.45 \mu \mathrm{m}$ membrane filter and then stored in $60 \mathrm{~mL}$ polythene bottles before chemical analyses. Samples for cation analysis were acidified to $\mathrm{pH}<2$ with ultrapure $\mathrm{HNO}_{3}$.

\subsection{Chemical Analysis}

The concentration of the major cations was determined by graphite furnace atomic absorption spectrometry (AAS; PE3100, Perkin-Elmer, Waltham, MA, USA) and inductively coupled plasma-atomic emission spectrometry (ICP-AES; JY-38plus, Jobin Yvon, Longjumeau, France). The contents of major anions were analyzed by ion chromatography (IC; Dx 300, Dionex Co., Sunnyvale, CA, USA). All chemical analyses were conducted at Korea Institute of Geoscience and Mineral Resources (KIGAM). The reliability of the chemical analyses was estimated by calculating the charge imbalances between the cation and anions; the percentage of charge balance was within $\pm 6 \%$.

\subsection{Statistical Analysis}

The correlation and factor analyses for major ions of groundwater and spring water were applied to understand their relationship among chemical variances. In particular, factor analysis was performed to extract major factors having highly loaded eigenvalues of chemical variances. IBM Statistical Package for Social Sciences (Armonk, NY, USA), version 25 analysis software was used for this statistical analysis [6]. R-mode factor analyses were performed as principal components after Varimax rotation, which allowed verification of factor loadings related to percentages of the total variance within the data.

\subsection{Thermodynamic Modeling}

The saturation index (SI) was calculated to define the state of thermodynamic equilibrium between potential reactive minerals and secondary minerals and groundwater and spring water by using a software program PHREEQC (Denver, CO, USA) [7,8]. The equilibrium calculation was supported by thermodynamic equilibrium constant installed at WATEQ4F data base. The calculation procedure can be converged using Newton-Raphson iteration method.

\section{Study Area}

Jeju Island is a Tertiary volcanic island of $1847 \mathrm{~km}^{2}$ area with an elliptical shape of $74 \mathrm{~km}$ in a long diameter and a short diameter of $32 \mathrm{~km}$. Mt. Halla, the highest peak located at the central part of the island, rises $1950 \mathrm{~m}$ above sea level. Jeju Island has a mild oceanic climate throughout the year with a narrow annual temperature variation. Annual mean temperature and precipitation of Jeju Island from 2009 to 2018 are $17.1^{\circ} \mathrm{C}$ and $1704 \mathrm{~mm} /$ year, respectively. Precipitation in the Mt. Halla in the central area of the island is over two times as large as the coastal area. Over about 60 percent of annual precipitation occurs during the monsoon season from June to September, which is a common weather characteristic for eastern Asia [9].

The geologic map of Jeju Island is shown in Figure 2a [10]. The island is mainly composed of porous volcanic lava flows formed from multiple eruptions that occurred from the late Pliocene to the Quaternary period, with less sedimentary rocks imbedded between volcanic rocks. The volcanic rocks of the island are known as basalt, trachybasalt, basaltic trachyandesite, trachyandesite and trachyte. The geochemical studies supported that the volcanic rocks have characteristics of oceanic island basalt and the eruption which is the hot-spot related to the mantle-plumes [11]. Seogwipo Formation which is distributed under volcanic rock consists of gravelly sandstone, sandstone, sandy mudstone and 
mudstone, characterized by abundant bioclastic shells [12-14]. Figure $2 b$ shows the simplified geologic cross section $\left(\mathrm{A}-\mathrm{A}^{\prime}\right)$ of Figure $2 \mathrm{a}$. Underneath the Seogwipo Formation, the Unconsolidated Formation (U Formation), which is composed of unconsolidated sediments such as gray to light gray fine sand and silt, and the basement of granite are located sequentially [15]. As shown in Figure 1b, three types of groundwater exist on Jeju Island; high level, parabasal, and basal groundwater according to their depth and seawater mixing [16,17]. High-level groundwater occurs only at high-altitude areas and has no contact with seawater. Basal groundwater mixed with sea water exist in the eastern part of cross section. The elevation of the Seogwipo Formation plays a role to determine the location and shape of the freshwater and seawater interface, which differs from the east coast to the west coast (Figure 1b). The Seogwipo Formation with a low permeability acts as an aquiclude in other areas without southeastern coastal area $[16,18]$.

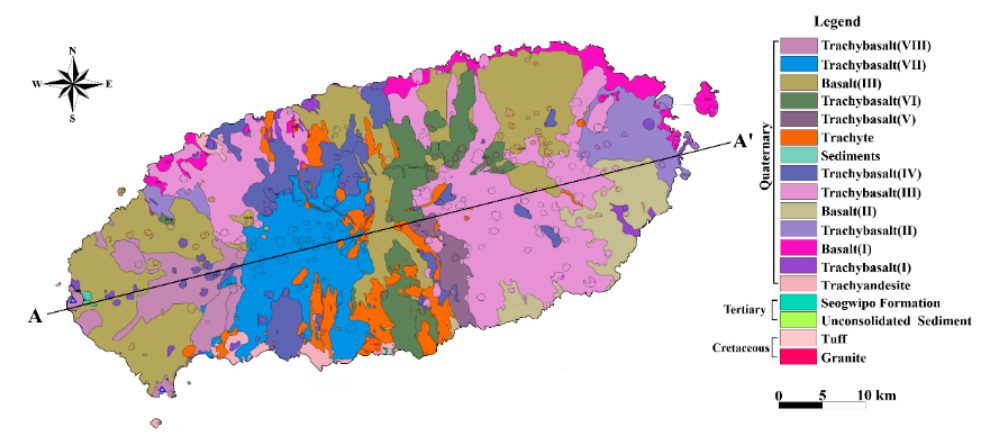

(a)

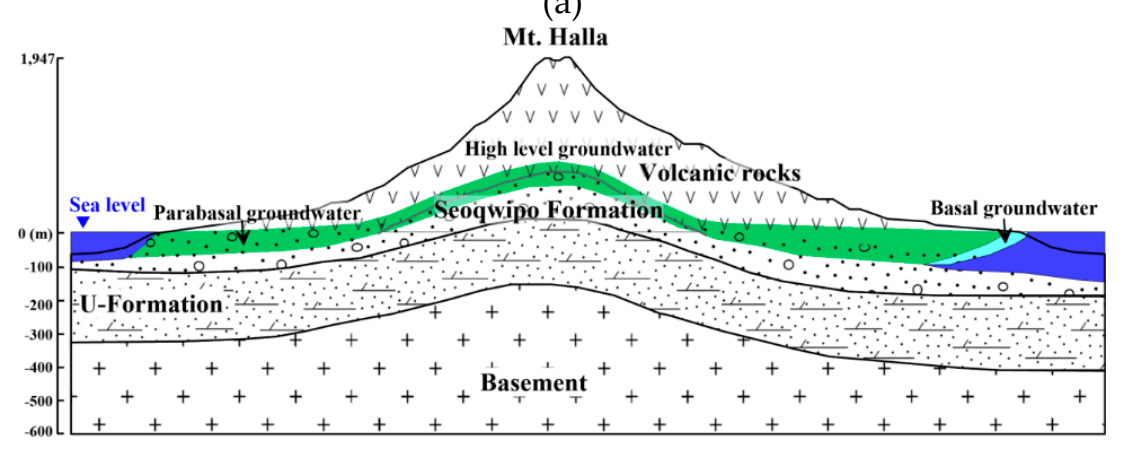

(b)

Figure 2. Geologic map (a) and simplified geologic cross section $\left(\mathrm{A}-\mathrm{A}^{\prime}\right)$ including three aquifer types of groundwater $(\mathbf{b})$ of Jeju Island $[4,10]$.

Based on the drilled core data and water level data from total 203 wells, Kim et al. (2011) suggested that main aquifers are the clinkers and fracture zones developed in feldspar olivine basalt, acicular feldspar olivine basalt, feldspar augite olivine basalt, augite olivine basalt, aphanitic basalt, trachyandesite, trachybasalt, feldspar augite basalt, feldspar basalt and hyaloclastite within Seogwipo Formation [19]. Basaltic rocks are known to be highly permeable with hydraulic conductivity in the range 84.6 to $552.2 \mathrm{~m} / \mathrm{d}[15,16,20]$. In consequence of the highly permeable layer, groundwater recharge rate in the island was estimated to be $38.7-45.8 \%$ of the average precipitation $[10,20,21]$. However, the Seogwipo Formation with a low permeability acts as an aquiclude [16,18]. The data of chlorofluorocarbons (CFCs) as an environmental tracer of groundwater in Jeju Island suggested that the groundwater has a relative young age (15 to 25 year) which indicates a rapid flow in a porous aquifer after the recharge [22]. Tritium age of groundwater was estimated as a residence time from 9.57 to above 40 year with an average age of 17.8 year [23].

The change of land use can be an important factor threatening groundwater quality in Jeju Island. The urban area has been continuously enlarged along the coastal areas below $100 \mathrm{~m}$ altitude. The 31 
golf resorts of 3361 ha, horse farms of 15,375 ha and tangerine orchards of 20,021 ha, which can be potential pollution sources have been also developed in the areas below $400 \mathrm{~m}$ in elevation. However, the mountain areas above $400 \mathrm{~m}$ altitude are well conserved as a natural environment.

\section{Results and Discussion}

\subsection{Geochemical Composition and Water Type}

The statistical values of in situ measurement data and chemical compositions of groundwater and spring water in Jeju Island are given in Tables 1 and 2, respectively, according to three zones of their occurrence altitude (below $100 \mathrm{~m}, 100$ to $400 \mathrm{~m}$ and above $400 \mathrm{~m}$ ) and sampling months (July and October). The chemical composition of groundwater and spring water can be influenced by the occurrence altitude because groundwater and spring water regionally flow from a higher recharge area including Mt. Halla to a lower discharge area (a coastal area). The potential factors controlling the chemical composition of groundwater and spring water would be mineral compositions of rock contacting along their flow paths, anthropogenic inputs according to land use, and sea water intrusion along a coastal line. The $\mathrm{pH}$, electrical conductivity and major-ion contents of groundwater and spring water are statistically presented in a box-whisker diagram according to two seasons (July and October) and their altitude $(<100 \mathrm{~m}, 100-400 \mathrm{~m}$ and $400<\mathrm{m})$ (Figure 3$)$. The diagram shows a graphical representation of key values (i.e., minimum, 25th percentile, median, 75 th percentile and maximum; endpoint is $2.5 \%$ and $97.5 \%$ of the range). The $\mathrm{pH}$ value of groundwater shows a weak alkaline range of median 7.22-7.77, which is a slightly higher range than that of spring water (6.74-6.89). Electrical conductivity of spring water has a higher value than that of groundwater, and an electrical conductivity of groundwater and spring water shows an increasing trend from a high altitude to a low altitude.

The content of $\mathrm{Na}^{+}, \mathrm{Cl}^{-}$and $\mathrm{SO}_{4}{ }^{2-}$ between spring water and groundwater shows a great difference in low land areas below $100 \mathrm{~m}$ elevation, that is, their median concentrations in spring water have much higher values than those of groundwater, whereas their concentrations in a high land area (above 100 m elevation) show the similar range. $\mathrm{Na}^{+}, \mathrm{Cl}^{-}$and $\mathrm{SO}_{4}{ }^{2-}$ contents of spring water and groundwater in coastal areas amount to maximum $696 \mathrm{mg} / \mathrm{L}, 1380 \mathrm{mg} / \mathrm{L}, 185 \mathrm{mg} / \mathrm{L}$, respectively, whereas their maximum concentrations in high land areas decrease greatly below $20 \mathrm{mg} / \mathrm{L}$. This implies the effect of seawater mixing into spring water along the coastal area in addition to the origin from mineral-water interaction. We will discuss further sea water mixing through the correlation and factor analyses in the next section.

$\mathrm{HCO}_{3}{ }^{-}$concentration of groundwater and spring water ranges from 3.1 to $240 \mathrm{mg} / \mathrm{L}$, showing an increasing trend from a high land area to a low land area. The natural process such as the dissolution of carbonate minerals, atmospheric and soil $\mathrm{CO}_{2}$ gas would be major mechanisms to supply $\mathrm{HCO}_{3}{ }^{-}$ into the groundwater as follows:

$$
\mathrm{CaCO}_{3}+\mathrm{CO}_{2}+\mathrm{H}_{2} \mathrm{O} \leftrightarrow \mathrm{Ca}^{2+}+2 \mathrm{HCO}_{3}^{-}, \mathrm{CO}_{2}+\mathrm{H}_{2} \mathrm{O} \leftrightarrow \mathrm{H}^{+}+\mathrm{HCO}_{3}^{-}
$$

The anthropogenic $\mathrm{CO}_{2}$ gas as well as a natural origin $\mathrm{CO}_{2}$ can be supplied from municipal waste site, oxidation of organic materials leaked from old latrines, and sewage system in urban area. In this study, excess carbon dioxide partial pressure $\left(\mathrm{EpCO}_{2}\right)$, that is the $\mathrm{CO}_{2}$ content of water samples relative to pure water was introduced to estimate $\mathrm{HCO}_{3}{ }^{-}$content originated from anthropogenic $\mathrm{CO}_{2}$ gas [24,25]:

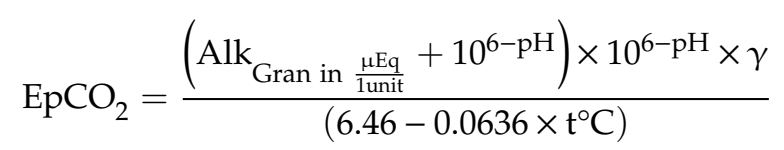

where, $\gamma$ and $t$ are correction terms for ion activity and temperature $\left(\mathrm{t}^{\circ} \mathrm{C}\right)$, respectively. For the calculations, $\gamma$ has been used the values calculated from the PHREEQC program. In situ measured temperature value was used as water temperature in Equation (2). 
Table 1. Statistical data of chemical compositions of groundwater samples according to the altitude in Jeju Island (Unit: $\mathrm{mg} / \mathrm{L})$.

\begin{tabular}{|c|c|c|c|c|c|c|c|c|c|c|c|c|c|c|c|c|c|}
\hline $\begin{array}{l}\text { Altit } \\
\text { (el. }\end{array}$ & & Month & $\begin{array}{l}\text { Temp } \\
\left({ }^{\circ} \mathrm{C}\right)\end{array}$ & $\mathrm{pH}$ & $\begin{array}{c}\text { Eh } \\
(\mathrm{mV})\end{array}$ & $\begin{array}{c}\text { EC } \\
\left(\mu \mathrm{Scm}^{-1}\right)\end{array}$ & $\mathrm{Na}^{+}$ & $\mathrm{Ca}^{2+}$ & $\mathrm{Mg}^{2+}$ & $\mathbf{K}^{+}$ & $\mathrm{Sr}^{2+}$ & $\mathbf{F}^{-}$ & $\mathrm{Cl}^{-}$ & $\mathrm{NO}_{3}{ }^{-}$ & $\mathrm{SO}_{4}{ }^{2-}$ & $\mathrm{HCO}_{3}^{-}$ & $\mathrm{SiO}_{2}$ \\
\hline \multirow{6}{*}{$<100$} & \multirow{2}{*}{ Max. } & July & 20.3 & 8.44 & 200 & 530 & 70.3 & 26.2 & 30.6 & 8.08 & 0.08 & 0.45 & 114 & 96.1 & 27.1 & 234 & 40.8 \\
\hline & & October & 18.7 & 8.98 & 241 & 1136 & 197 & 35.1 & 33.3 & 16.3 & 0.15 & 0.39 & 397 & 61.6 & 57.0 & 240 & 40.2 \\
\hline & \multirow{2}{*}{ Min. } & July & 14.8 & 6.60 & 126 & 97.3 & 7.74 & 5.90 & 2.66 & 2.49 & 0.00 & 0.02 & 8.63 & 0.00 & 1.39 & 18.3 & 21.6 \\
\hline & & October & 14.6 & 6.70 & 57.0 & 109 & 7.07 & 4.79 & 2.61 & 2.37 & 0.01 & 0.02 & 7.75 & 0.40 & 1.59 & 19.8 & 22.0 \\
\hline & \multirow{2}{*}{ Ave. } & July & 17.1 & 7.34 & 176 & 200 & 17.9 & 10.9 & 8.85 & 4.05 & 0.02 & 0.07 & 24.4 & 33.7 & 5.51 & 46.7 & 29.3 \\
\hline & & October & 16.3 & 7.47 & 188 & 227 & 21.3 & 11.2 & 8.09 & 4.94 & 0.04 & 0.06 & 33.1 & 24.0 & 6.63 & 56.7 & 31.5 \\
\hline \multirow{6}{*}{ 100 400 } & \multirow[b]{2}{*}{ Max. } & July & 18.4 & 7.84 & 171 & 172 & 11.7 & 10.3 & 9.11 & 4.95 & 0.03 & 0.06 & 19.1 & 43.1 & 6.01 & 68.7 & 35.7 \\
\hline & & October & 16.5 & 8.29 & 278 & 219 & 30.9 & 16.3 & 9.26 & 3.41 & 0.03 & 0.10 & 49.2 & 39.8 & 7.71 & 97.6 & 39.1 \\
\hline & \multirow{2}{*}{ Min. } & July & 14.3 & 6.47 & 156 & 50.9 & 5.15 & 2.94 & 1.45 & 1.79 & 0.00 & 0.03 & 2.28 & 0.00 & 1.31 & 8.85 & 9.58 \\
\hline & & October & 13.8 & 6.35 & -15 & 62.3 & 4.58 & 2.84 & 1.69 & 1.74 & 0.00 & 0.03 & 4.93 & 0.26 & 1.29 & 15.4 & 2.44 \\
\hline & \multirow{2}{*}{ Ave. } & July & 16.1 & 7.22 & 162 & 90.1 & 7.60 & 5.34 & 3.98 & 2.61 & 0.01 & 0.04 & 8.91 & 11.8 & 2.46 & 29.1 & 26.9 \\
\hline & & October & 15.4 & 7.37 & 178 & 103 & 7.91 & 4.79 & 3.74 & 2.41 & 0.01 & 0.05 & 9.69 & 6.77 & 2.34 & 32.7 & 28.5 \\
\hline \multirow{6}{*}{$400<$} & \multirow{2}{*}{ Max. } & July & 15.5 & 8.18 & - & 79.0 & 6.47 & 4.54 & 4.50 & 3.26 & 0.01 & 0.05 & 6.29 & 0.00 & 1.62 & 43.0 & 32.0 \\
\hline & & October & 15.4 & 8.33 & 188 & 102 & 6.00 & 4.78 & 5.17 & 2.68 & 0.00 & 0.06 & 6.31 & 0.63 & 1.68 & 51.9 & 35.1 \\
\hline & \multirow{2}{*}{ Min. } & July & 15.1 & 7.32 & - & 45.3 & 4.49 & 2.97 & 1.65 & 1.85 & 0.00 & 0.04 & 4.90 & 0.00 & 1.41 & 22.3 & 24.6 \\
\hline & & October & 14.9 & 7.05 & 176 & 59.6 & 4.30 & 3.03 & 1.87 & 1.76 & 0.00 & 0.03 & 4.91 & 0.42 & 1.40 & 24.4 & 26.7 \\
\hline & \multirow{2}{*}{ Ave. } & July & 15.3 & 7.72 & - & 63.3 & 5.57 & 3.59 & 2.91 & 2.48 & 0.00 & 0.05 & 5.68 & 0.00 & 1.51 & 29.9 & 27.3 \\
\hline & & October & 15.1 & 7.77 & 182 & 80.7 & 5.23 & 3.68 & 3.19 & 2.16 & 0.00 & 0.05 & 5.59 & 0.55 & 1.53 & 34.1 & 29.9 \\
\hline
\end{tabular}


Table 2. Statistical data of chemical compositions of spring water samples according to the altitude in Jeju Island (Unit: $\mathrm{mg} / \mathrm{L}$ ).

\begin{tabular}{|c|c|c|c|c|c|c|c|c|c|c|c|c|c|c|c|c|c|}
\hline $\begin{array}{r}\text { Altitu } \\
\text { (el. 1 }\end{array}$ & & Month & $\begin{array}{l}\text { Temp } \\
\left({ }^{\circ} \mathrm{C}\right)\end{array}$ & $\mathrm{pH}$ & $\begin{array}{c}\text { Eh } \\
(\mathrm{mV})\end{array}$ & $\begin{array}{c}\mathrm{EC} \\
\left(\mu \mathrm{S} \mathrm{cm}^{-1}\right)\end{array}$ & $\mathrm{Na}^{+}$ & $\mathrm{Ca}^{2+}$ & $\mathrm{Mg}^{2+}$ & $\mathrm{K}^{+}$ & $\mathrm{Sr}^{2+}$ & $\mathbf{F}^{-}$ & $\mathrm{Cl}^{-}$ & $\mathrm{NO}_{3}{ }^{-}$ & $\mathrm{SO}_{4}{ }^{2-}$ & $\mathrm{HCO}_{3}^{-}$ & $\mathrm{SiO}_{2}$ \\
\hline \multirow{6}{*}{$<100$} & \multirow[b]{2}{*}{ Max. } & July & 19.2 & 8.12 & - & 3510 & 655 & 50.1 & 85.3 & 35.2 & 0.22 & 0.19 & 1280 & 200 & 177 & 113 & 42.6 \\
\hline & & October & 18.6 & 8.05 & 237 & 4490 & 696 & 63.3 & 82.5 & 36.9 & 0.24 & 0.35 & 1380 & 205 & 185 & 162 & 43.6 \\
\hline & \multirow{2}{*}{ Min. } & July & 15.1 & 6.19 & - & 133 & 13.6 & 6.36 & 6.9 & 3.21 & 0.01 & 0.04 & 17.4 & 21.8 & 4.48 & 33.6 & 18.4 \\
\hline & & October & 14.8 & 6.19 & 146 & 183 & 10.5 & 8.71 & 7.32 & 3.05 & 0.01 & 0.00 & 16.3 & 23.6 & 4.40 & 32.0 & 2.50 \\
\hline & \multirow{2}{*}{ Ave. } & July & 16.9 & 6.89 & - & 931 & 138 & 27.0 & 24.3 & 12.5 & 0.09 & 0.08 & 259 & 80.9 & 45.1 & 52.3 & 27.6 \\
\hline & & October & 17.3 & 6.94 & 195 & 1003 & 128 & 23.6 & 22.6 & 10.1 & 0.10 & 0.08 & 234 & 66.2 & 38.3 & 63.8 & 29.8 \\
\hline \multirow{6}{*}{$100 \sim 400$} & \multirow[b]{2}{*}{ Max. } & July & 16.7 & 7.02 & - & 290 & 15.8 & 29.1 & 20.5 & 1.60 & 0.14 & 0.04 & 34.3 & 160 & 4.24 & 25.0 & 18.6 \\
\hline & & October & 16.6 & 7.54 & 224 & 284 & 13.0 & 20.5 & 12.6 & 6.00 & 0.09 & 0.04 & 25.6 & 85.0 & 5.60 & 41.2 & 32.9 \\
\hline & \multirow[b]{2}{*}{ Min. } & July & 14.8 & 6.70 & - & 44.4 & 4.17 & 3.02 & 1.76 & 1.46 & 0.00 & 0.00 & 5.04 & 4.46 & 1.89 & 12.2 & 17.7 \\
\hline & & October & 15.4 & 6.48 & 188 & 54.3 & 3.91 & 2.50 & 1.47 & 1.32 & 0.01 & 0.00 & 3.8 & 0.93 & 1.42 & 22.0 & 22.2 \\
\hline & \multirow{2}{*}{ Ave. } & July & 15.8 & 6.86 & - & 167 & 9.99 & 16.1 & 11.1 & 1.53 & 0.07 & 0.02 & 19.7 & 82.2 & 3.07 & 18.6 & 18.2 \\
\hline & & October & 16.0 & 6.92 & 211 & 190 & 9.74 & 12.0 & 7.58 & 2.96 & 0.05 & 0.02 & 16.9 & 41.3 & 3.39 & 33.3 & 26.0 \\
\hline \multirow{6}{*}{$400<$} & \multirow[b]{2}{*}{ Max. } & July & 13.4 & 7.02 & - & 39.9 & 4.36 & 2.23 & 1.52 & 1.02 & 0.00 & 0.08 & 7.39 & 2.69 & 2.03 & 12.2 & 17.3 \\
\hline & & October & 13.0 & 7.55 & 239 & 48.8 & 4.41 & 2.61 & 1.73 & 0.97 & 0.01 & 0.08 & 6.60 & 2.86 & 2.00 & 16.8 & 20.0 \\
\hline & \multirow{2}{*}{ Min. } & July & 9.40 & 6.20 & - & 9.40 & 1.35 & 0.67 & 0.23 & 0.46 & 0.00 & 0.00 & 1.58 & 0.00 & 0.77 & 4.58 & 6.03 \\
\hline & & October & 10.1 & 6.37 & 210 & 14.2 & 1.16 & 0.63 & 0.18 & 0.39 & 0.00 & 0.00 & 1.50 & 0.00 & 0.90 & 3.10 & 7.01 \\
\hline & \multirow[b]{2}{*}{ Ave. } & July & 11.7 & 6.74 & - & 25.5 & 2.87 & 1.82 & 0.93 & 0.72 & 0.00 & 0.03 & 3.75 & 0.70 & 1.39 & 9.31 & 10.9 \\
\hline & & October & 11.4 & 6.79 & 224 & 36.0 & 2.93 & 1.93 & 0.98 & 0.68 & 0.00 & 0.02 & 3.81 & 0.99 & 1.45 & 11.0 & 13.4 \\
\hline
\end{tabular}



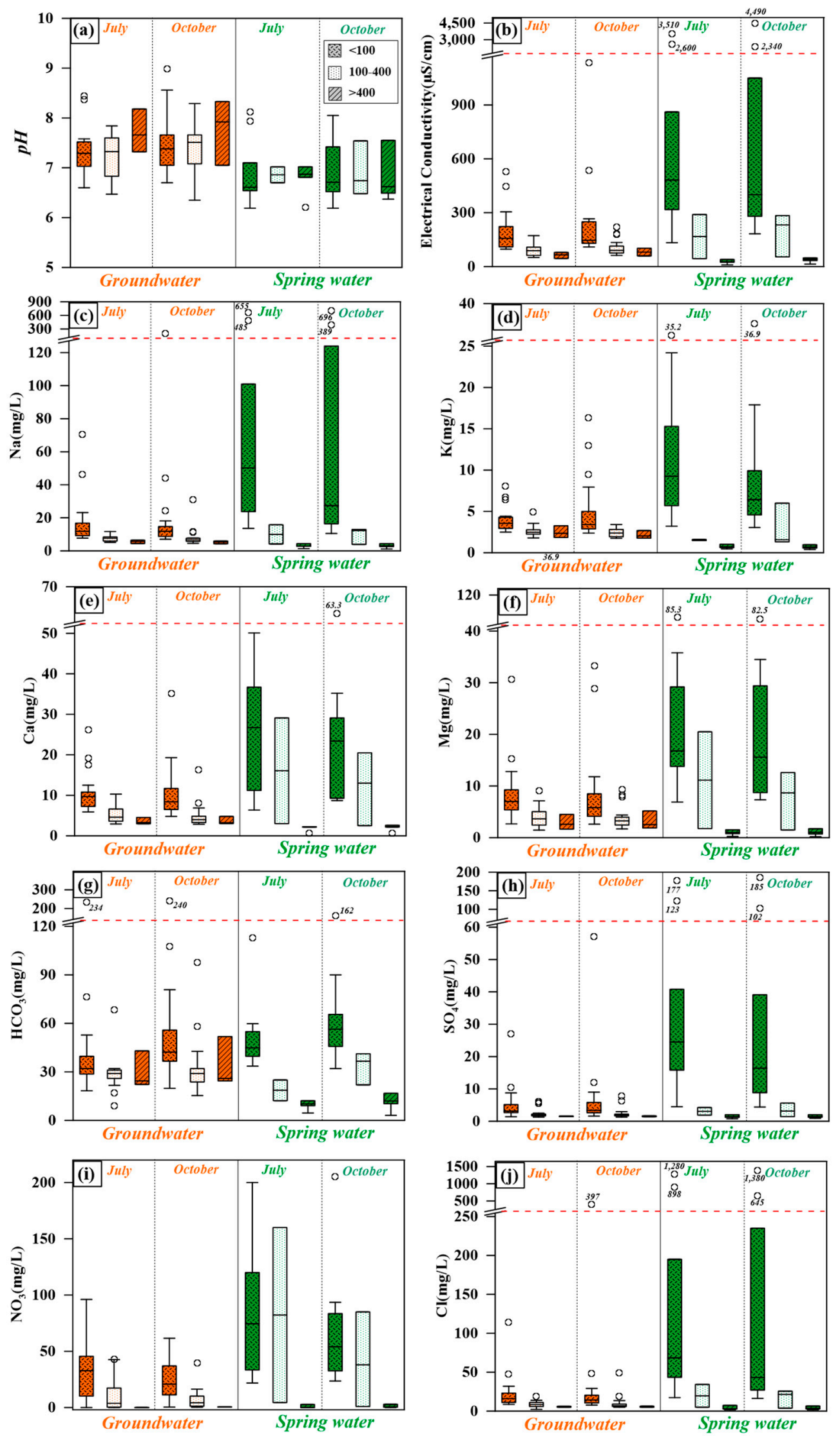

Figure 3. Box-whisker statistical diagrams of $\mathrm{pH}$, electrical conductivity and major ions of groundwater and spring water in Jeju Island. (a), (b), (c), (d), (e), (f), (g), (h), (i) and (j) are the variation of $\mathrm{pH}, \mathrm{EC}$, $\mathrm{Na}, \mathrm{K}, \mathrm{Ca}, \mathrm{Mg}, \mathrm{HCO}_{3}, \mathrm{SO}_{4}, \mathrm{NO}_{3}$ and $\mathrm{Cl}$ as a function of altitude, respectively. 
$\mathrm{pH}$ endpoint is the $\mathrm{pH}$ value from the endpoint of the alkalinity measurement. The endpoint $\mathrm{pH}$ is usually 4.3 ; hence the $10^{(6-p H e n d p o i n t)}$ term is $31.6 \mu \mathrm{Eq} / \mathrm{L}$. In addition, $\mathrm{pCO}_{2}$, which is closely related with $\mathrm{EpCO}_{2}$ of water sample, was also calculated by the PHREEQC program. The $\mathrm{pCO}_{2}$ level of soil layer in open system is generally known as the range of $10^{-1.5}$ to $10^{-2.5} \mathrm{~atm}$, and atmospheric $\mathrm{CO}_{2}$ is in the equilibrium state at $10^{-3.5} \mathrm{~atm}$ [26]. Figure 4a shows the positive relationship between $\mathrm{pCO}_{2}$ and $\mathrm{EpCO}_{2}$ of groundwater and spring water, and $\mathrm{pCO}_{2}$ of all water samples except one spring water are below soil $\mathrm{pCO}_{2}$ range. The very low regression coefficients $\left(\mathrm{R}^{2}, 0.1-0.12\right)$ between $\mathrm{NO}_{3}$ and $\mathrm{EpCO}_{2}$ of groundwater and spring water indicate no distinct relationship (Figure $4 \mathrm{~b}$ ). Thus, this indicates that $\mathrm{HCO}_{3}$ in water samples was mainly originated from natural reaction or sea water mixing, regardless of the dissolution of $\mathrm{CO}_{2}$ gas generated from pollution sources.
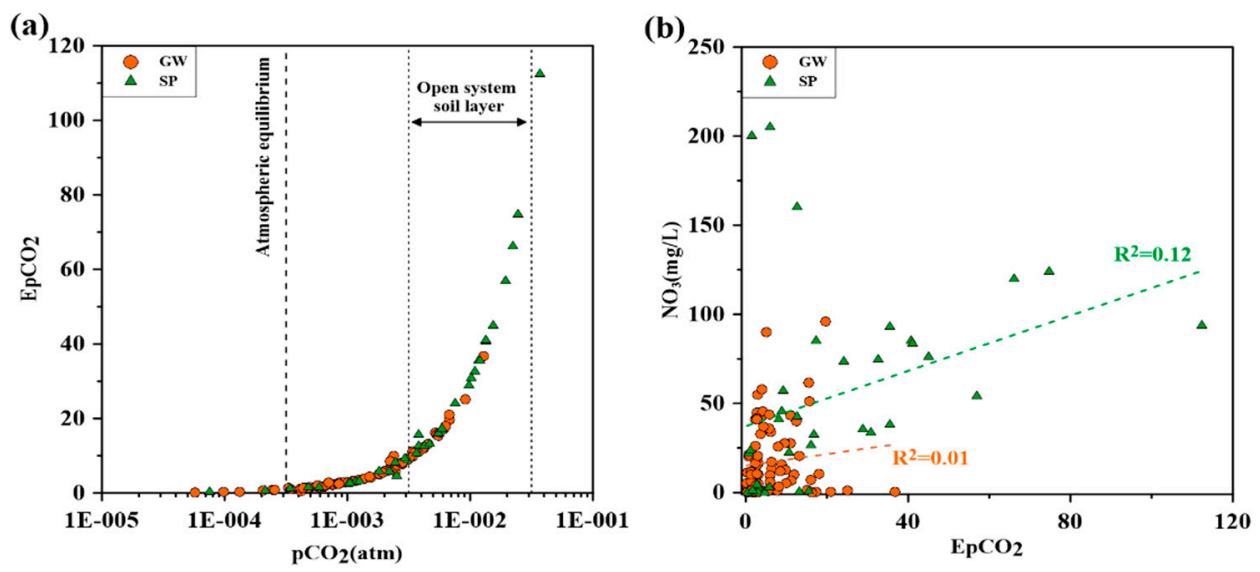

Figure 4. The relationships between $\mathrm{pCO}_{2}$ and $\mathrm{EpCO}_{2}(\mathbf{a})$, and between $\mathrm{NO}_{3}$ and $\mathrm{EpCO}_{2}(\mathbf{b})$.

Nitrate-nitrogen $\left(\mathrm{NO}_{3}-\mathrm{N}\right)$ contamination of groundwater is major concern for a sustainable use of groundwater resources in many countries [26-32]. Nitrate concentration as a drinking water is regulated to be lower than $45 \mathrm{mg} / \mathrm{L}$ as $\mathrm{NO}_{3}{ }^{-}$or $10 \mathrm{mg} / \mathrm{L}$ as $\mathrm{NO}_{3}-\mathrm{N}$ in Korea. The maximum $\mathrm{NO}_{3}{ }^{-}$ concentrations of groundwater and spring water in Jeju Island amount to $96.1 \mathrm{mg} / \mathrm{L}$ and $205 \mathrm{mg} / \mathrm{L}$, respectively. About $50 \%$ of spring water exceed the regulation limit $(45 \mathrm{mg} / \mathrm{L})$ of $\mathrm{NO}_{3}{ }^{-}$. It is assumed that $\mathrm{NO}_{3}{ }^{-}$in water samples was mainly derived from pollution sources such as domestic sewage, nitrogen fertilizer of agriculture activity and resort facilities in low and mid-mountain area.

In Figure 3, the statistical range of $\mathrm{Ca}^{2+}, \mathrm{Mg}^{2+}$ and $\mathrm{NO}_{3}{ }^{-}$contents shows a similar trend; (1) their concentrations in spring water below $400 \mathrm{~m}$ elevation show higher levels than those in groundwater, (2) their concentration shows an increasing trend from higher areas to lower areas. Such trend implies that $\mathrm{Ca}$ and $\mathrm{Mg}$ are originated from the common source with nitrate besides the dissolution process of $\mathrm{Mg}(\mathrm{Ca})$-bearing-minerals such as anorthite, augite and olivine of basaltic rocks. We will discuss further their origin through a statistical analysis method in the next section.

To delineate the contamination, sea water mixing and chemical types of groundwater and spring water, major cations and anions (expressed as meq percentiles) are shown in a trilinear plot (Piper diagram; Figure 5). The diagram indicates that the chemical compositions of fresh groundwater and spring water of the $\mathrm{Ca}(\mathrm{Na})-\mathrm{HCO}_{3}$ type have been changed along two different paths: (1) A contamination path ( $\mathrm{Ca}-\mathrm{Cl}, \mathrm{NO}_{3}$ type), and (2) a sea water mixing path ( $\mathrm{Na}-\mathrm{Cl}\left(\mathrm{SO}_{4}\right)$ type). The chemical type coincides with the occurrence altitude of groundwater and spring water, that is, sea water mixing water (Na-Cl $\left(\mathrm{SO}_{4}\right)$ type) and contamination water $\left(\mathrm{Ca}-\mathrm{Cl}, \mathrm{NO}_{3}\right.$ type) occur mainly in low land areas (coastal areas), and fresh water of $\mathrm{Ca}(\mathrm{Na})-\mathrm{HCO}_{3}$ type occur mainly in middle and high land (mountain) areas. 

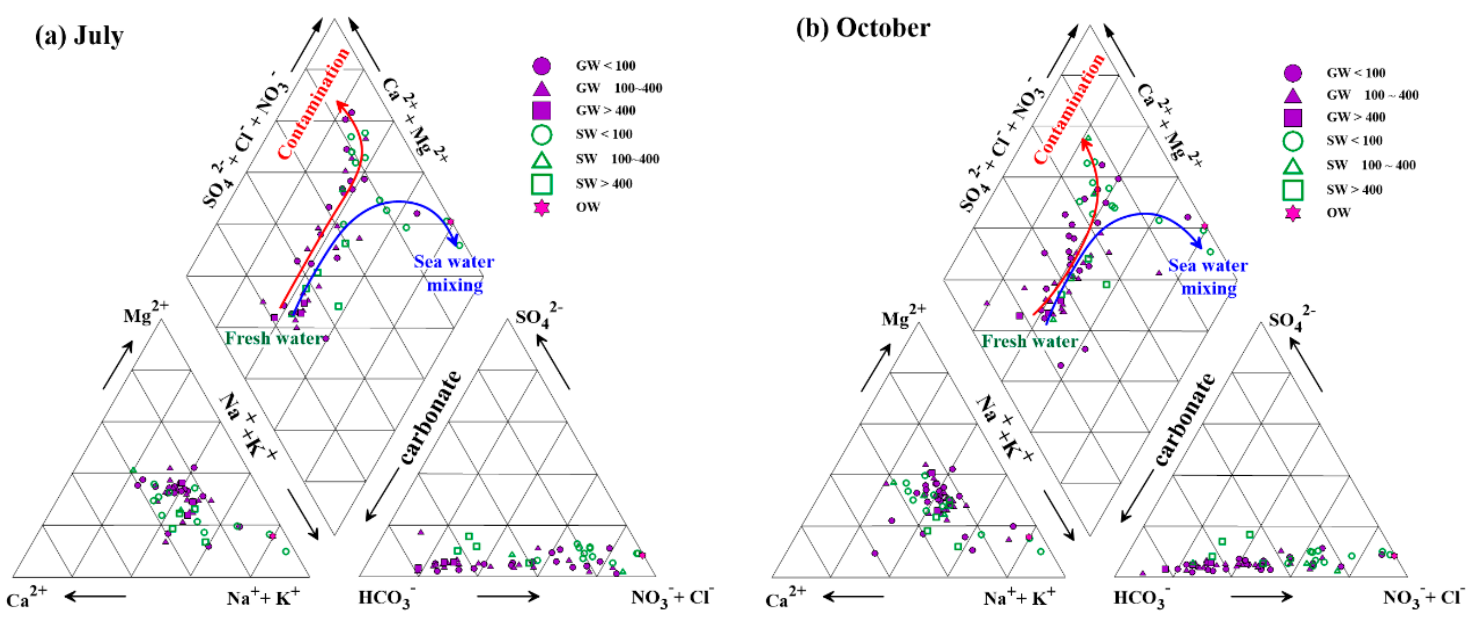

Figure 5. Piper diagram of the major chemical compositions of groundwater (GW, solid symbols), spring water (SW, open symbols) and sea water (OW) expressed in milli-equivalent percentages. (a) and (b) represent July and October as sampling seasons, respectively.

Figure 6 represents the kriging results of concentrations of $\mathrm{NO}_{3}$ and $\mathrm{Cl}$, which are the indicators of anthropogenic contamination and sea water mixing of both groundwater and spring water samples, respectively. According to the figure, the concentrations of $\mathrm{NO}_{3}$ and $\mathrm{Cl}$ show a distinct gradation with the occurrence altitude of groundwater and spring water. $\mathrm{NO}_{3}$ concentration has an increasing trend from high mountain areas toward low coastal areas, with a seasonal variation. The highest content of $\mathrm{Cl}$ as an indicator of sea water mixing are restricted at coastal and low areas in the southeastern part of Jeju Island. The restricted sea water intrusion is closely related with the distribution of Seogwipo Formation. The elevation of the Seogwipo Formation plays a role to determine the location and shape of the freshwater and seawater interface, which differs from the east coast to the west coast (Figure 1b). The Seogwipo Formation with a low permeability acts as an aquiclude in other areas except southeastern coastal area $[16,18]$. The high grade contour of chlorine in the southeastern coastal area of Jeju Island is due to the distribution of Seogwipo Formation under sea water level, which results in sea water intrusion into basal groundwater.

(a) July

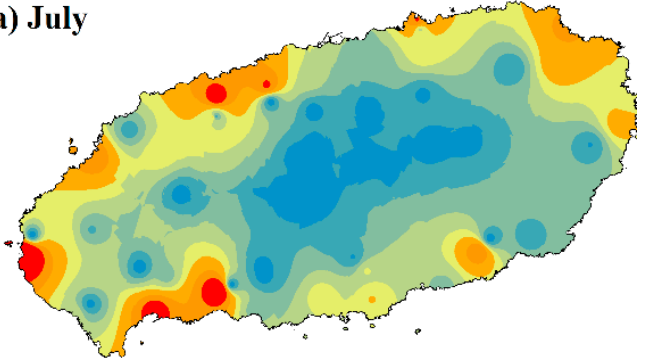

(c) July

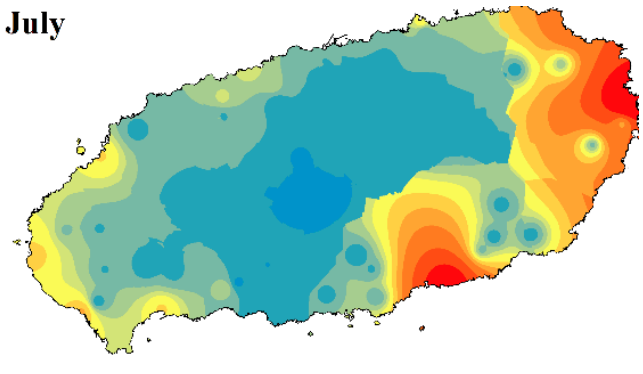

(b) October
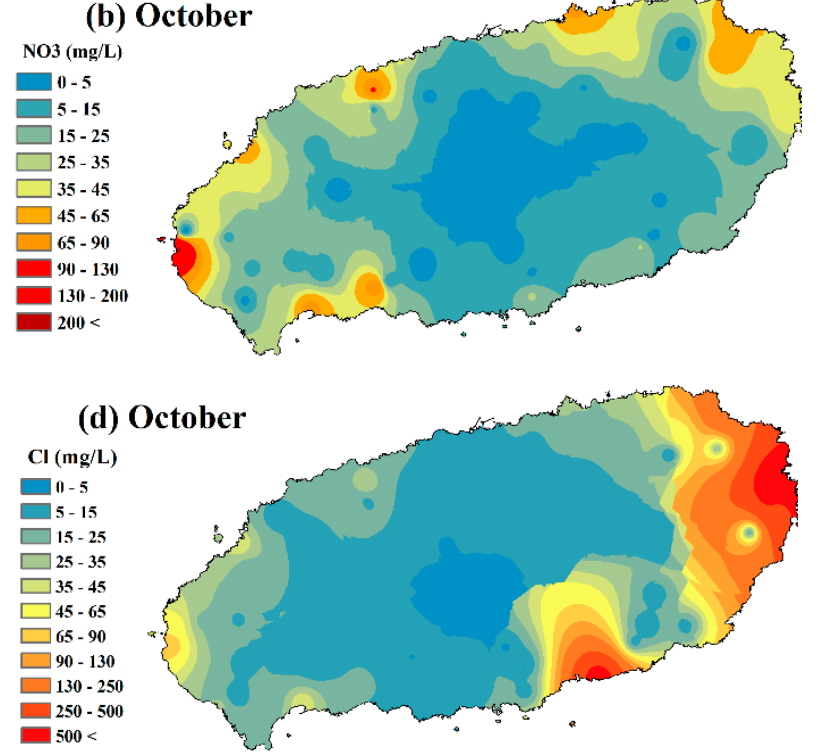

Figure 6. Kriging maps of the $\mathrm{NO}_{3}$ and $\mathrm{Cl}$ contents of groundwater and spring water in Jeju Island. (a) and (b) represent the kriging maps of $\mathrm{NO}_{3}$ concentration at July and October, respectively; (c) and (d) show the kriging maps of $\mathrm{Cl}$ concentration at July and October, respectively. 
The high $\mathrm{NO}_{3}$ content is recognized along the northern and the southern coastal areas of the western part of Jeju Island. Nitrate in groundwater and spring water may be primarily derived from pollution sources, i.e., agricultural activities, municipal sewage and horse farms along coastal and low areas. In Figure 6, the difference of $\mathrm{NO}_{3}$ content contour between July and October is likely to be due to the following dilution effect of heavy rainfall during a monsoon season (June to September). The kriging result of a seasonal variation corresponds to a shorter contamination path line in October than July on the Piper diagram.

\subsection{Correlation Analysis and Factor Analysis}

The statistical method such as multivariate analysis can be used to characterize its geochemical processes through data reduction and classification with respect to chemical composition of groundwater. When correlation analysis and factor analysis are applied to chemical data of groundwater, dominant processes can be identified as common factors that are sets of variables having strong associations with one another [33-37].

In this study, correlation and factor analyses were used to delineate the possible common sources such as natural chemical weathering, anthropogenic inputs and sea water mixing for the chemical composition of groundwater and spring water. The variables for correlation and factor analyses were $\mathrm{Na}^{+}, \mathrm{K}^{+}, \mathrm{Mg}^{+}, \mathrm{Ca}^{+}, \mathrm{HCO}_{3}{ }^{-}, \mathrm{Cl}^{-}, \mathrm{SO}_{4}{ }^{2-}, \mathrm{NO}_{3}{ }^{-}, \mathrm{SiO}_{2}, \mathrm{~F}^{-}$, and $\mathrm{Sr}^{2+}$.

The results of correlation coefficient among major ions of groundwater and spring water are summarized in Table 3. Chlorine as an indicator of sea water mixing has high Pearson's correlation coefficients with $\mathrm{Na}(0.998), \mathrm{SO}_{4}(0.989), \mathrm{K}(0.901)$, and $\mathrm{Mg}(0.882)$ in order. $\mathrm{NO}_{3}$ as a representative composition of anthropogenic contamination, shows high correlation coefficients with $\mathrm{Ca}(0.856)$ and $\mathrm{Sr}$ (0.699). Although the concentration of $\mathrm{Ca}, \mathrm{Mg}$ and $\mathrm{NO}_{3}$ shows a similar trend in the box-whisker diagram (Figure 3), however, a correlation coefficient between $\mathrm{NO}_{3}$ and $\mathrm{Mg}$ has a low value of 0.438 , which means a low contribution from a common source. $\mathrm{HCO}_{3}$ originated from natural chemical processes has high to moderate correlation coefficients with $\mathrm{F}(0.701)$ and $\mathrm{Ca}(0.522)$.

Table 3. The matrix of correlation coefficients among chemical components of groundwater and spring water in Jeju Island.

\begin{tabular}{|c|c|c|c|c|c|c|c|c|c|c|c|}
\hline & $\mathrm{Na}$ & $\mathrm{Ca}$ & $\mathrm{Mg}$ & $\mathbf{K}$ & $\mathrm{Sr}$ & $\mathrm{SiO}_{2}$ & $\mathbf{F}$ & $\mathrm{Cl}$ & $\mathrm{NO}_{3}$ & $\mathrm{SO}_{4}$ & $\mathrm{HCO}_{3}$ \\
\hline \multirow{2}{*}{$\mathrm{Na}$} & 1 & $0.324^{* *}$ & $0.879 * *$ & $0.904^{* *}$ & $0.478^{* *}$ & -0.030 & $0.314^{* *}$ & $0.998^{* *}$ & 0.119 & $0.990 * *$ & 0.095 \\
\hline & & 0.003 & $<0.001$ & $<0.001$ & $<0.001$ & 0.747 & 0.005 & $<0.001$ & 0.192 & $<0.001$ & 0.300 \\
\hline \multirow{2}{*}{$\mathrm{Ca}$} & 0.324 ** & 1 & 0.630 ** & $0.489^{* *}$ & $0.869 * *$ & 0.166 & 0.191 * & 0.322 ** & $0.856^{* *}$ & $0.393^{* *}$ & $0.522 * *$ \\
\hline & 0.003 & & $<0.001$ & $<0.001$ & $<0.001$ & 0.069 & 0.036 & 0.003 & $<0.001$ & $<0.001$ & $<0.001$ \\
\hline \multirow{2}{*}{$\mathrm{Mg}$} & $0.879 * *$ & 0.630 ** & 1 & $0.878^{* *}$ & $0.685^{* *}$ & 0.163 & 0.363 ** & 0.882 ** & $0.438^{* *}$ & 0.891 ** & $0.359 * *$ \\
\hline & $<0.001$ & $<0.001$ & & $<0.001$ & $<0.001$ & 0.075 & $<0.001$ & $<0.001$ & $<0.001$ & $<0.001$ & $<0.001$ \\
\hline \multirow{2}{*}{$\mathbf{K}$} & 0.904 ** & $0.489 * *$ & $0.878 * *$ & 1 & $0.575^{* *}$ & 0.093 & $0.340 * *$ & $0.901^{* *}$ & $0.265^{* *}$ & $0.924 * *$ & $0.269^{* *}$ \\
\hline & $<0.001$ & $<0.001$ & $<0.001$ & & $<0.001$ & 0.311 & $<0.001$ & $<0.001$ & 0.003 & $<0.001$ & 0.003 \\
\hline \multirow{2}{*}{$\mathrm{Sr}$} & $0.478^{* *}$ & $0.869 * *$ & 0.685 ** & $0.575^{* *}$ & 1 & 0.041 & 0.141 & $0.483^{* *}$ & $0.699^{* *}$ & $0.529^{* *}$ & $0.421^{* *}$ \\
\hline & $<0.001$ & $<0.001$ & $<0.001$ & $<0.001$ & & 0.654 & 0.122 & $<0.001$ & $<0.001$ & $<0.001$ & $<0.001$ \\
\hline \multirow{2}{*}{$\mathrm{SiO}_{2}$} & -0.030 & 0.166 & 0.163 & 0.093 & 0.041 & 1 & 0.183 * & -0.040 & 0.184 * & -0.040 & $0.382 * *$ \\
\hline & 0.747 & 0.069 & 0.075 & 0.318 & 0.654 & & 0.045 & 0.667 & 0.043 & 0.666 & $<0.001$ \\
\hline \multirow{2}{*}{$\mathbf{F}$} & $0.314^{* *}$ & 0.191 * & 0.363 ** & $0.340^{* *}$ & 0.141 & $0.183 *$ & 1 & $0.269 * *$ & -0.055 & $0.283^{* *}$ & 0.720 ** \\
\hline & 0.005 & 0.036 & $<0.001$ & $<0.001$ & 0.122 & 0.045 & & 0.003 & 0.548 & 0.002 & $<0.001$ \\
\hline \multirow{2}{*}{$\mathrm{Cl}$} & $0.998 * *$ & $0.322^{* *}$ & $0.882 * *$ & $0.901^{* *}$ & $0.483^{* *}$ & -0.040 & $0.269 * *$ & 1 & 0.120 & $0.989 * *$ & 0.069 \\
\hline & $<0.001$ & 0.003 & $<0.001$ & $<0.001$ & $<0.001$ & 0.667 & 0.003 & & 0.190 & $<0.001$ & 0.454 \\
\hline \multirow{2}{*}{$\mathrm{NO}_{3}$} & 0.119 & $0.856^{* *}$ & $0.438 * *$ & $0.265^{* *}$ & $0.699 * *$ & 0.184 * & -0.055 & 0.120 & 1 & $0.192 *$ & $0.203 *$ \\
\hline & 0.192 & $<0.001$ & $<0.001$ & 0.003 & $<0.001$ & 0.043 & 0.548 & 0.190 & & 0.035 & 0.026 \\
\hline \multirow{2}{*}{$\mathrm{SO}_{4}$} & $0.990 * *$ & $0.393^{* *}$ & 0.891 ** & 0.924 ** & $0.529 * *$ & -0.040 & $0.283^{* *}$ & $0.989 * *$ & $0.192 *$ & 1 & 0.089 \\
\hline & $<0.001$ & $<0.001$ & $<0.001$ & $<0.001$ & $<0.001$ & 0.666 & 0.002 & $<0.001$ & 0.035 & & 0.334 \\
\hline \multirow{2}{*}{$\mathrm{HCO}_{3}$} & 0.095 & $0.522 * *$ & $0.359 * *$ & $0.269^{* *}$ & $0.421^{* *}$ & $0.382 * *$ & $0.720 * *$ & 0.069 & $0.203^{*}$ & 0.089 & 1 \\
\hline & 0.300 & $<0.001$ & $<0.001$ & 0.003 & $<0.001$ & $<0.001$ & $<0.001$ & 0.454 & 0.026 & 0.334 & \\
\hline
\end{tabular}

Note: ${ }^{* *}(P<0.01),{ }^{*}(P<0.05)$. 
The R-mode factor analysis was applied to obtain correlations among the chemical components of groundwater and spring water samples. Factor analysis was done as follows: The correlation matrix, the array of correlation coefficients for all possible pairs of variables, was calculated. Then, the matrix was diagonalized and its principal components (eigenvectors) were obtained. The so-called factor 1 is related to the largest eigenvalue and is able to explain the greatest amount of variance in the data set. The second factor (orthogonal and uncorrelated with the first one) explains the most of the remaining variance, and so forth [38].

The chemical composition of groundwater and spring water can be determined by potential mechanisms such as natural chemical weathering, anthropogenic inputs and seawater mixing. Hence, the concentration of chemical ions can be loaded by above three partial contributions. Factor analysis was applied to distinguish the main contributions for chemical ions.

Three factors were extracted to statistically represent the contributions influencing chemical composition of groundwater and spring water. The equimax rotation method with Kaise normalization was applied to extract the factors. Three significant factors explain $87 \%$ of total sample variance. The variance explanations of the factors are $43.82 \%$ for factor $1,25.11 \%$ for factor 2 , and $19.17 \%$ for factor 3, respectively.

Table 4 shows that variables of $\mathrm{Cl}, \mathrm{Na}, \mathrm{K}, \mathrm{SO}_{4}$ and $\mathrm{Mg}$ have high positive load scores (0.848-0.991) on factor 1 , and that the variables of $\mathrm{NO}_{3}, \mathrm{Ca}$ and $\mathrm{Sr}$ as factor 2 are highly loaded as the value of 0.813-0.946, and $\mathrm{HCO}_{3}$ and $\mathrm{F}$ as factor 3 have positive loadings of $0.833-0.904$. Three factors with different factor loads indicate that three contributions are involved in determining the chemical composition of groundwater and spring water with a different ratio. The $\mathrm{Cl}, \mathrm{NO}_{3}$ and $\mathrm{HCO}_{3}$ have the highest loads on factor 1, 2 and 3, respectively. A high concentration above average $\mathrm{Cl}$ content in fresh groundwater and spring water implies strongly sea water intrusion into spring water and groundwater along coastal areas.

Table 4. Equimax factor matrix of geochemical composition and factor scores of groundwater and spring water samples.

\begin{tabular}{cccc}
\hline Components & Factor1 & Factor 2 & Factor 3 \\
\hline $\mathrm{Na}$ & 0.991 & 0.079 & 0.025 \\
$\mathrm{Cl}$ & 0.991 & 0.089 & -0.012 \\
$\mathrm{SO}_{4}$ & 0.982 & 0.158 & -0.002 \\
$\mathrm{~K}$ & 0.905 & 0.244 & 0.160 \\
$\mathrm{Mg}$ & 0.848 & 0.411 & 0.223 \\
$\mathrm{NO}_{3}$ & 0.036 & 0.946 & 0.015 \\
$\mathrm{Ca}$ & 0.253 & 0.908 & 0.260 \\
$\mathrm{Sr}$ & 0.420 & 0.813 & 0.134 \\
$\mathrm{HCO}_{3}$ & 0.065 & 0.270 & 0.904 \\
$\mathrm{~F}$ & 0.315 & -0.145 & 0.833 \\
$\mathrm{SiO}_{2}$ & -0.096 & 0.144 & 0.571 \\
\hline Eigenvalue & 4.820 & 2.762 & 1.998 \\
\hline Cumulative & 4.820 & 7.582 & 9.580 \\
Eigenvalue & & 25.107 & 18.167 \\
\hline \% Variance & 43.819 & 68.926 & 87.093 \\
Explained & & & \\
\hline Cumulative & 43.819 & & \\
\% variance & & & \\
\hline
\end{tabular}

As described in the previous section, because $\mathrm{NO}_{3}$ has nothing to do with a lithologic source, it may be primarily introduced by pollution sources, i.e., agricultural activities, municipal sewage and horse farms, etc. From the calculation of $\mathrm{pCO}_{2}$ and $\mathrm{EpCO}_{2}$ in the previous section, it is evident that $\mathrm{HCO}_{3}$ is originated by the dissolution of carbonate minerals and atmospheric and soil $\mathrm{CO}_{2}$. Hence, 
factor $1\left(\mathrm{Na}, \mathrm{Cl}\right.$ and $\left.\mathrm{SO}_{4}\right)$, factor $2\left(\mathrm{NO}_{3}\right)$ and factor $3\left(\mathrm{HCO}_{3}\right)$ are assumed to be indicative ions of sea water mixing, contamination, mineral-water interaction as the main contributions for chemical composition of groundwater and spring water, respectively.

Figure 7 shows the relationship of factor loads among variables of groundwater and spring water. $\mathrm{Na}, \mathrm{Cl}$ and $\mathrm{SO}_{4}, \mathrm{NO}_{3}$ and $\mathrm{HCO}_{3}$ are plotted at each end member of factor 1, 2 and 3, respectively. Although ions such as $\mathrm{K}, \mathrm{Mg}, \mathrm{Ca}, \mathrm{SiO}_{2}, \mathrm{~F}$ and $\mathrm{Sr}$ have also high load values within main factor, they have effective load scores in other factors. In Figure $7 \mathrm{a}, \mathrm{Ca}, \mathrm{Sr}, \mathrm{Mg}$ and $\mathrm{K}$ have effective load values in both sea water mixing (factor 1) and contamination (factor 2), that indicates their origin from two sources with a different ratio. Figure $\mathrm{7b}$ shows that $\mathrm{Ca}, \mathrm{Mg}, \mathrm{K}$ and $\mathrm{Sr}$ are plotted in the middle zone between factor 1 and factor $3 . \mathrm{K}, \mathrm{Mg}, \mathrm{Sr}, \mathrm{Ca}$ and $\mathrm{SiO}_{2}$ have effective load scores in both factor 2 and factor 3 (Figure 7c).
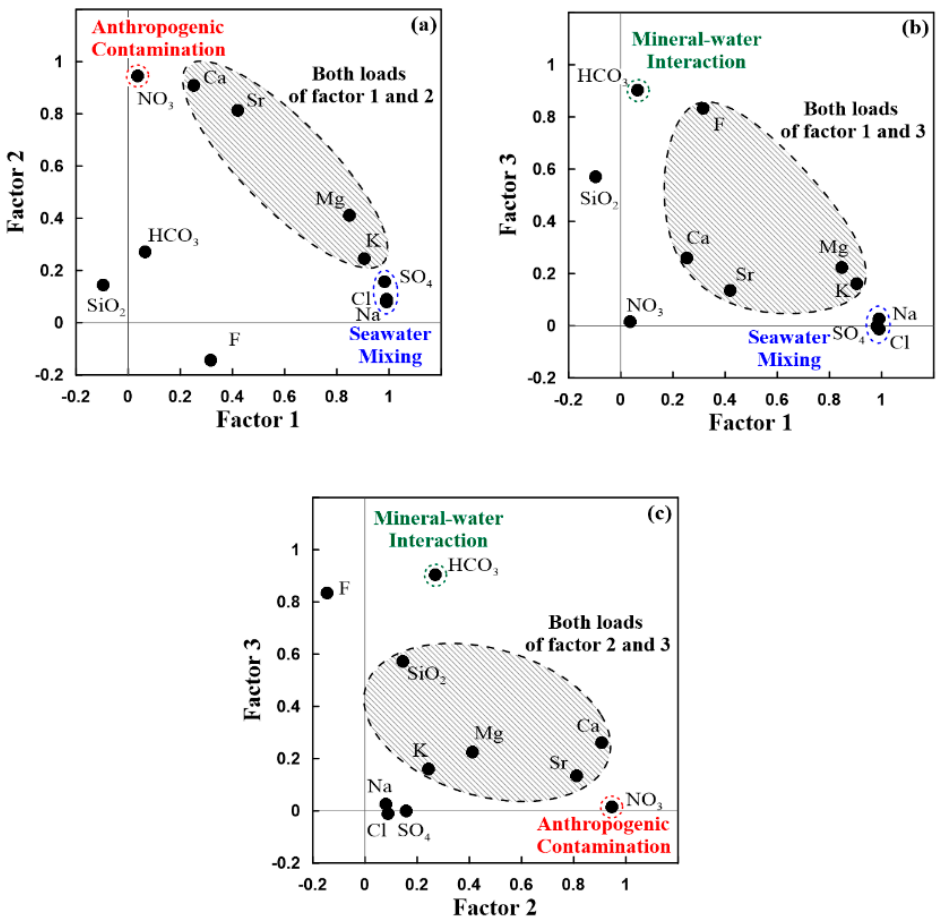

Figure 7. Distribution of variables among factors as produced by factor analysis. (a) Factor 1 vs Factor 2, (b) Factor 1 vs Factor 3, and (c) Factor 2 vs Factor 3.

Although $\mathrm{Na}, \mathrm{K}$ and $\mathrm{Mg}$ are highly loaded at factor 1, of course, they can be partly derived from weathering process of feldspar $\left((\mathrm{Na}, \mathrm{Ca}, \mathrm{K}) \mathrm{AlSi}_{3} \mathrm{O}_{8}\right)$, augite $\left(\mathrm{CaMgSi}_{2} \mathrm{O}_{6}\right)$ and olivine $\left((\mathrm{Mg}, \mathrm{Fe})_{2} \mathrm{SiO}_{4}\right)$, which are major minerals of basaltic rocks. $\mathrm{As}_{\mathrm{SiO}_{2}}$ has the highest load score (0.571) in factor 3, it also mainly originates from natural weathering process of above minerals.

It is not often that $\mathrm{Ca}$ and $\mathrm{Sr}$ highly loaded at factor 2 are originated from contamination sources. In case of high contaminated waters, however, they may be partly originated from pollution sources; e.g., a deicing material $\left(\mathrm{Ca}(\mathrm{Sr}) \mathrm{Cl}_{2}\right)$. As $\mathrm{Sr}$ shows very low concentration below $0.24 \mathrm{mg} / \mathrm{L}$, it can occur as a minor substitute of $\mathrm{Ca}$.

Fluorine can occur as a substitute of $\mathrm{OH}^{-}$in biotite rarely found in sedimentary rocks [39]. F of a low concentration below $0.45 \mathrm{mg} / \mathrm{L}$ has 0.315 load value in factor 1 and 0.833 load value in factor 3 , respectively. This means that $\mathrm{F}$ also comes partly from sea water as well as mineral-water interaction as a major source.

\subsection{Thermodynamic Equilibrium of Water-Mineral Interaction}

The saturation index (SI) calculated by using the software program PHREEQC was used to better define the geochemical evolution reaction along a regional flow path of groundwater and spring water, 
and to represent the thermodynamic equilibrium states between reactive minerals and groundwater and spring water in Jeju Island. SI values for certain minerals indicate the tendency for precipitation or the dissolution of these minerals: $\mathrm{SI}=0$ for thermodynamic equilibrium, SI $>0$ for oversaturation (precipitation conditions), and SI $<0$ for under-saturation (dissolution conditions). Here, the saturation index (SI) can be expressed in terms of ion activity product (IAP) and equilibrium constant (K) as follows: $\mathrm{SI}=\mathrm{IAP} / \mathrm{K}$. Thermodynamic equilibrium can only indicate the potential for such mineral phase transfers. In reality, there are a number of kinetic reasons which may cause systems to behave differently than predicted $[40,41]$. Nevertheless, the saturation index can be useful for examining potential secondary phases and the dissolution of minerals of interest in aquifer system.

From the results of thermodynamic equilibrium calculation for given chemical data of groundwater and spring water samples, SI values were extracted for major minerals (feldspar, augite and olivine) of volcanic rocks in Jeju Island. For SI calculation, thermodynamic equilibrium constant data of albite, anorthite, tremolite, forsterite, diopside, and phlogopite, which are kinds of feldspar, augite, olivine and biotite groups as major minerals of basaltic and sedimentary rocks, were used from the values installed in the WATEQ4F data base.

The saturation indices between chemical data of all water samples and potential reactive minerals were statistically summarized according to the altitude of water samples (Table 5). The result indicates that most of waters were under-saturated with respect to major minerals except a few water samples of positive SI values with respect to tremolite. However, they were oversaturated with respect to illite, kaolinite and Ca-smectite as secondary minerals, which are randomly found at drilled cores and sedimentary rocks $[42,43]$. Except $\mathrm{HCO}_{3}$ and $\mathrm{F}$, which are indicative ions of factor 3, major ions such as $\mathrm{Ca}, \mathrm{Mg}, \mathrm{Na}, \mathrm{K}$, and $\mathrm{SiO}_{2}$ have low load scores (0.025-0.570) at factor 3 indicating the main contribution by mineral-water interaction. These major ions are also to be main chemical composition of feldspar, augite, olivine and biotite in Jeju volcanic rocks. Then, thermodynamic under-saturation state in most of water samples with respect to above minerals correspond to low load scores of factor 3 . Therefore, it is estimated that mineral-water interaction has a low contribution for the production of major ions such as $\mathrm{Ca}, \mathrm{Mg}, \mathrm{Na}, \mathrm{K}$, and $\mathrm{SiO}_{2}$ in most of waters.

Table 5. Statistical saturation indices of chemical composition of groundwater (A) and spring water (B) with respect to major reactive minerals in Jeju Island.

\begin{tabular}{|c|c|c|c|c|c|c|c|}
\hline \multicolumn{2}{|c|}{ Altitude (el. m) } & Albite ${ }^{1)}$ & Anorthite $^{2)}$ & Diopside $^{3)}$ & Forsterite $^{4)}$ & Phlogopite 5) & Tremolite ${ }^{6)}$ \\
\hline \multicolumn{8}{|c|}{ (A) } \\
\hline \multirow{3}{*}{$<100$} & Max. & -0.75 & -3.89 & -0.85 & -6.50 & -2.59 & 6.59 \\
\hline & Min & -20.4 & -4.70 & -7.53 & -12.9 & -12.4 & -16.3 \\
\hline & Ave. & -2.79 & -4.45 & -5.15 & -10.5 & -8.47 & -7.83 \\
\hline \multirow{3}{*}{$100 \sim 400$} & Max. & -1.58 & -4.34 & -4.03 & -9.42 & -6.67 & -3.84 \\
\hline & Min & -3.73 & -14.7 & -10.5 & -15.9 & -17.8 & -27.8 \\
\hline & Ave. & -2.07 & -5.41 & -6.37 & -11.7 & -10.4 & -12.1 \\
\hline \multirow{3}{*}{$400<$} & Max. & -1.72 & -4.52 & -3.15 & -8.61 & -5.67 & -0.99 \\
\hline & Min & -2.20 & -4.91 & -6.35 & -11.7 & -10.2 & -12.0 \\
\hline & Ave. & -2.02 & -4.77 & -4.65 & -10.0 & -7.61 & -6.00 \\
\hline \multicolumn{8}{|c|}{ (B) } \\
\hline \multirow{3}{*}{$<100$} & Max. & -0.22 & -3.56 & -1.15 & -6.57 & -1.82 & 6.08 \\
\hline & Min & -2.22 & -5.67 & -8.96 & -14.4 & -14.5 & -21.1 \\
\hline & Ave. & -1.39 & -4.67 & -6.41 & -11.7 & -10.1 & -12.2 \\
\hline \multirow{3}{*}{$100 \sim 400$} & Max. & -2.40 & -4.72 & -7.39 & -12.6 & -12.3 & -15.9 \\
\hline & Min & -2.63 & -5.23 & -8.05 & -13.4 & -13.1 & -18.2 \\
\hline & Ave. & -2.52 & -4.98 & -7.72 & -13.0 & -12.7 & -17.1 \\
\hline \multirow{3}{*}{$400<$} & Max. & -2.69 & -5.35 & -8.61 & -14.1 & -13.8 & -20.2 \\
\hline & Min & -5.14 & -8.53 & -14.3 & -19.6 & -23.5 & -40.5 \\
\hline & Ave. & -3.66 & -6.45 & -10.6 & -15.9 & -17.2 & -27.3 \\
\hline
\end{tabular}


Figure 8 shows the kriging contour map for SI values of all water samples with respect to major minerals using a semi-variogram method. The figure agrees with above explanation about an increasing trend of SI value from the central area including Mt. Halla to right and left coastal areas in Jeju Island. Whereas near-equilibrium state of some waters (maximum SI of -0.22) with respect to albite in a coastal area may results from high $\mathrm{Na}$ content due to sea water mixing, the waters are still under-saturated with respect to anorthite (Ca-plagioclase). The comparison of saturation indices indicates that groundwater and spring water for diopside and tremolite are evolved rather than those for forsterite and phlogopite. A few waters for diopside and tremolite are in near-equilibrium and oversaturated state. Considering the residence time (average 17 year) of groundwater in highly permeable aquifers of basaltic rocks [23], it is inferred that the reaction time is not enough to reach the equilibrium and oversaturation states through mineral-water interaction in a low temperature aquifer. The saturation indices have an increasing trend from higher altitude areas to lower altitude areas. Ignoring the effect of sea water mixing and anthropogenic input, this trend indicates that although groundwater and spring water dose not fully reach to thermodynamic equilibrium through mineral-water interaction, they have been hydrochemically evolved from higher mountain areas (recharge areas) to lower coastal areas (discharge areas) along regional flow paths.
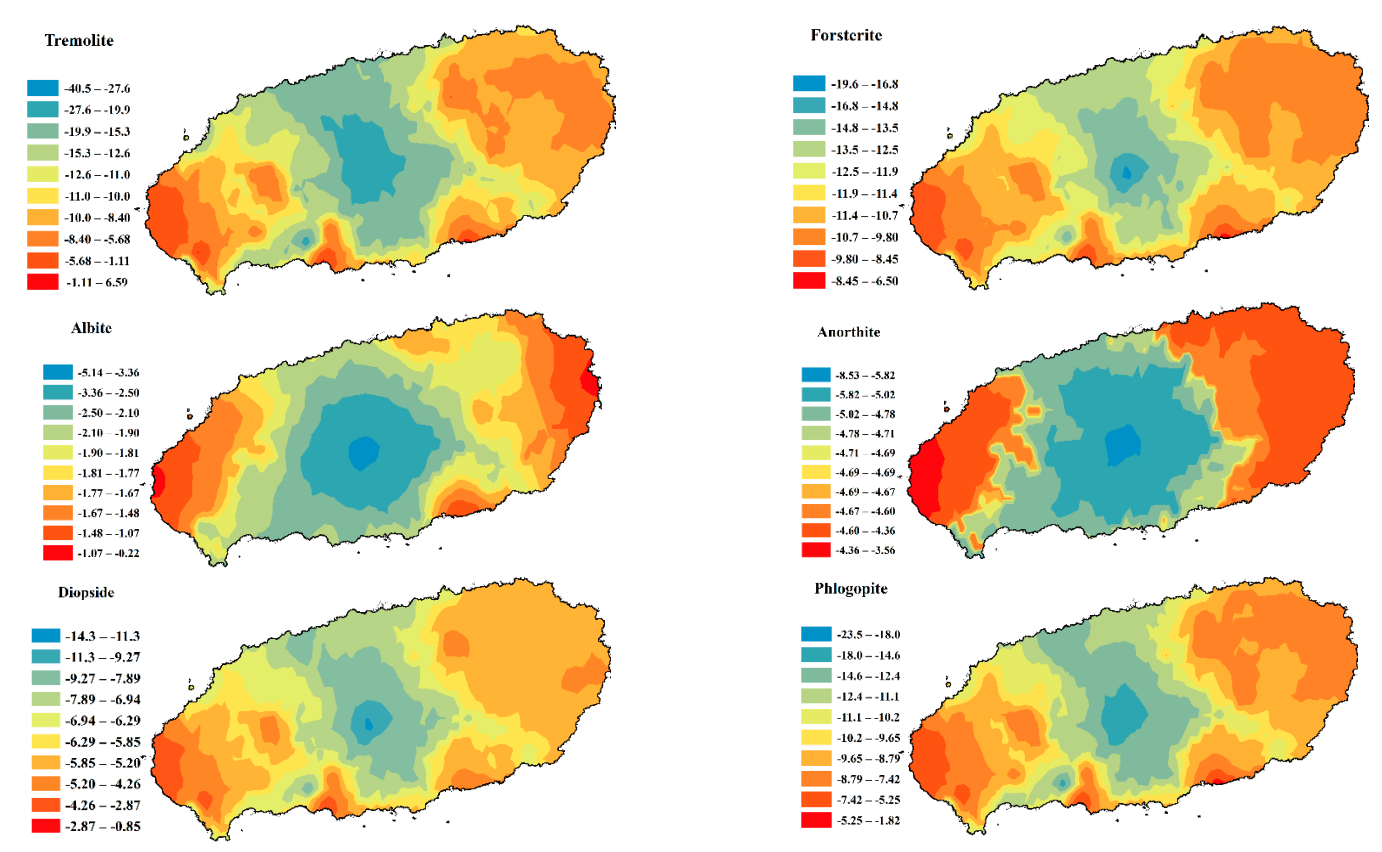

Figure 8. Kriging map of saturation indices between potential reactive minerals and chemical composition of groundwater and spring water samples in Jeju Island.

\section{Conclusions}

This study presented major contributions influencing the chemical composition of groundwater and spring water at Jeju Island. The main conclusions based on the results of this study are as follows:

(1) The $\mathrm{pH}$ and chemical composition of groundwater and spring water at Jeju Island show distinct differences according to their occurrence altitudes; higher saline and nitrate contents in lower areas. Box-Whisker and Piper diagrams indicate that the groundwater and spring water are divided as three chemical types through two different changing paths from an initial fresh water: 1) A fresh water type $\left.\left(\mathrm{Ca}, \mathrm{Na}-\mathrm{HCO}_{3}\right), 2\right)$ a sea water mixing type $\left(\mathrm{Na}-\mathrm{Cl}, \mathrm{SO}_{4}\right)$, and 3$)$ an anthropogenic contamination type $\left(\mathrm{Ca}-\mathrm{NO}_{3}, \mathrm{Cl}\right)$;

(2) By factor analysis, three main factors which can explain about $87 \%$ of chemical variances of water samples were extracted. $\mathrm{Na}^{+}, \mathrm{Cl}^{-}$and $\mathrm{SO}_{4}{ }^{2-}$ of factor $1, \mathrm{NO}_{3}{ }^{-}$of factor 2 , and $\mathrm{HCO}_{3}{ }^{-}$of factor 3 , which have the highest load values are originally indicative ions of sea water mixing, contamination 
and mineral-water interaction, respectively. Considering effective factor load values, other ions can be commonly derived by two or three original sources;

(3) Sea water intrusion in the eastern part of Jeju Island may be attributed to the distribution of Seogwipo Formation, which plays a role as an aquiclude preventing sea water intrusion in other coastal areas, under sea level. Nitrate contamination is closely related with agricultural activities, horse farms and municipal sewage, which are known as main pollution sources in coastal and mid-mountain areas at Jeju Island;

(4) The saturation indices from thermodynamic equilibrium calculation indicate that mineral-water interaction undergoes in aquifer except a few over-saturated waters with respect to major minerals of basaltic rocks. Thermodynamic under-saturation states in most of water samples with respect to feldspar, augite, olivine and biotite correspond to their load scores at factor 3. That is, mineral-water interaction has a relative low contribution for the origin of $\mathrm{Ca}, \mathrm{Mg}, \mathrm{Na}, \mathrm{K}$, and $\mathrm{SiO} 2$ in most of waters. The non-equilibrium state in most of waters with respect to major minerals may be due to insufficient time for enough mineral-water interaction with a highly permeable aquifer.

Author Contributions: B.D.L., C.H.J., J.H.Y., Y.C.L. and Y.J.L. conceived and designed the research project. B.D.L., C.H.J., C.O.C., Y.C.L., Y.H.O. and Y.J.L. performed the fieldwork and collected the water samples. Y.C.L., Y.J.L., H.W.J. and J.W.H. conducted the graphical work, statistical and thermodynamic analyses. All authors have read and agreed to the published version of the manuscript.

Funding: This research was financially supported by a Basic Research Project (20-3411) of the Korea Institute of Geoscience and Mineral Resources (KIGAM), funded by the Ministry of Science and ICT of Korea, and by the Daejeon University research fund (20173610).

Conflicts of Interest: The authors declare no conflict of interest.

\section{References}

1. Jeju Special Self-Governing Province Home Page. Available online: https://www.jeju.go.kr/open/stats/list/ population.htm (accessed on 1 March 2020).

2. Ko, T.H.; Kang, J.M.; Lim, J.H. Economic Effect Analysis of Tourism Industry in Jeju, 1st ed.; Development Institute (JDI) Press: Jeju-si, Jeju-do, Korea, 2012; pp. 1-121. ISBN 978-89-6010-227-9 93320.

3. Lee, Y.D. Characteristics of groundwater quality by elevation in Cheju Island. J. KoSES 2001, 5, 65-75.

4. Koh, E.H.; Lee, S.H.; Kaown, D.; Moon, H.S.; Lee, E.; Lee, K.K.; Kang, B.R. Impacts of land use change and groundwater management on long-term nitrate-nitrogen and chloride trends in groundwater of Jeju Island, Korea. Environ. Earth Sci. 2017, 20, 76-176. [CrossRef]

5. Kim, G.B.; Kim, J.W.; Won, J.H.; Koh, G.W. Regional trend analysis for groundwater quality in Jeju Island-focusing on chloride and nitrate concentrations. J. Korea Water Resour. Assoc. 2007, 40, 469-483. [CrossRef]

6. IBM SPSS Statistic Version 25. 2017. Available online: https://www.ibm.com/kr-ko/products/spss-statistics/ details (accessed on 22 October 2019).

7. PHREEQC. (Computer File) Water Chemistry, Computer Programs Geochemistry. Version 3.0; US Geological Survey (USGS): Denver, CO, USA, 1999. Available online: https://www.usgs.gov/software/phreeqc-version-3 (accessed on 22 October 2019).

8. Parkhurst, D.L. User's guide to PHREEQC-A computer program for speciation, reaction-path, advective-transport, and inverse geochemical calculations. U.S. Geol. Surv. 1995, 8, 1-143.

9. Lee, J.Y.; Lee, K.K. Use of hydrologic time series data for identification of recharge mechanism in a fractured bedrock aquifer system. J. Hydrol. 2000, 229, 190-201. [CrossRef]

10. Korea Institute of Geoscience and Mineral Resources (KIGAM). Explanatory Note of the Jeju (Baekado, Jinnampo) Sheet (1:250,000); KIGAM Report; Geological and Mining Institute Korea: Seoul, Korea, 2000; pp. 1-59.

11. KIGAM. Assessment of the Sustainable Yield on Groundwater in Jeju and Discovery of the Functional Groundwater; KIGAM: Daejeon, Korea, 2011.

12. Korea Institute of Geoscience and Mineral Resources (KIGAM). Geologic Report of the Jeju-Aewol Sheet (1:50,000); KIGAM Report; Geological and Mining Institute Korea: Seoul, Korea, 1998; pp. 1-290. 
13. Korea Institute of Geoscience and Mineral Resources (KIGAM). Geologic Report of the Moseulpo-Hanlim Sheet (1:50,000); KIGAM Report; Geological and Mining Institute Korea: Seoul, Korea, 2000; pp. 1-56.

14. Korea Institute of Geoscience and Mineral Resources (KIGAM). Geologic Report of the Segwipo-Hahyori Sheet (1:50,000); KIGAM Report; Geological and Mining Institute Korea: Seoul, Korea, 2000; pp. 1-163.

15. Won, J.H.; Kim, J.W.; Koh, G.W.; Lee, J.Y. Evaluation of hydrogeological characteristics in Jeju Island, Korea. Geosci. J. 2005, 9, 33-46. [CrossRef]

16. Won, J.H.; Lee, J.Y.; Kim, J.W.; Koh, G.W. Groundwater occurrence on Jeju Island, Korea. Hydrogeol. J. 2006, 14, 532-547. [CrossRef]

17. Jeju Special Self-Governing Province. Comprehensive Plans for Managing Water Resources in Jeju (2013-2022); Jeju Special Self-Governing Province: Jeju-do, Korea, 2018; pp. 1-366.

18. Koh, G.W. Characteristics of the Groundwater and Hydrogeologic Implication of the Seogwipo Formation in Cheju Island. Ph.D. Thesis, Busan National University, Busan, Korea, 20 July 1997.

19. Kim, B.S.; Hamm, S.Y.; Lee, C.M.; Ok, S.I.; Cha, E.J.; Ko, Y.S. Features of regional hydrogeology and groundwater distribution of volcanic rocks in Jeju Island. J. Geol. Soc. Korea 2011, 47, 263-273.

20. Hahn, J.S.; Hahn, K.S.; Kim, C.K.; Kim, N.J.; Hahn, C. Sustainable yield of groundwater resources of the Cheju Island. (In Korean with English abstract.). J. Geol. Soc. Korea 1994, 1, 33-50.

21. Choi, H.M.; Lee, J.Y.; Ha, K.; Kim, G.P. The study on time series analysis of groundwater data and groundwater recharge in Jeju Island. J. Eng. Geol. 2011, 21, 337-348, (In Korean with English abstract). [CrossRef]

22. Koh, D.C.; Cheon, S.H.; Park, K.H. Characterization of groundwater quality and recharge using periodic measurements of hydrogeochemical parameters and environmental tracers in basaltic aquifers of Jeju Island. J. Soil Ground. Environ. 2007, 12, 60-71.

23. Yoon, Y.Y.; Lee, K.Y.; Cho, S.Y.; Kim, Y.; Ko, K.S. The study of tritium analysis in Jeju Island groundwater. In Proceedings of the Korean Society of Analytical Sciences Conference, Seoul, Korea, 20-21 November 2008; p. 111.

24. Neal, C.; House, W.A.; Down, K. An assessment of excess carbon dioxide partial pressures in natural waters based on $\mathrm{pH}$ and alkalinity measurements. Sci. Total Environ. 1998, 210-211, 173-185. [CrossRef]

25. Neal, C.; House, W.A.; Jarvie, H.P.; Eatherall, A. The significance of dissolved carbon dioxide in major lowland rivers entering the North Sea. Sci. Total Environ. 1998, 210-211, 187-203. [CrossRef]

26. Appelo, C.A.J.; Postma, D. Geochemistry, Groundwater and Pollution, A.A.; Balkema Publishers: Rotterdam, The Nederland, 1996; ISBN 978-9054101062.

27. Nolan, B.T.; Stoner, J.D. Nutrients in groundwaters of the conterminous United States, 1992-1995. Environ. Sci. Technol. 2000, 34, 1156-1165. [CrossRef]

28. Stites, W.; Kraft, G.J. Nitrate and chloride loading to groundwater from an irrigated north-central U.S. sand-plain vegetable field. J. Environ. Qual. 2001, 30, 1176-1184. [CrossRef]

29. Chen, W.F.; Liu, T.K. Dissolved oxygen and nitrate of groundwater in Choshui Fan-Delta, western Taiwan. Environ. Geol. 2003, 44, 731-737. [CrossRef]

30. Babiker, I.S.; Mohamed, M.A.A.; Terao, H.; Kato, K.; Ohta, K. Assessment of groundwater contamination by nitrate leaching from intensive vegetable cultivation using geographical information system. Environ. Int. 2004, 29, 1009-1017. [CrossRef]

31. Erisman, J.W.; Sutton, M.A.; Galloway, J.; Kilmont, Z.; Winiwarter, W. How a century of ammonia synthesis changed the world. Nat. Geosci. 2008, 1, 636-639. [CrossRef]

32. Kurtzman, D.; Shapira, R.; Bar-Tal, A.; Fine, P.; Russo, D. Nitrate fluxes to groundwater under citrus orchards in Mediterranean climate: Observations, calibrated models, simulations and agro-hydrological conclusions. J. Contam. Hydrol. 2013, 151, 93-104. [CrossRef]

33. Usunoff, E.J.; Guzman-Guzman, A. Multivariate analysis in hydrochemistry: An example of the use factor and correspondence analyses. Groundwater 1989, 27, 27-34. [CrossRef]

34. Ritzi, R.W.; Wright, S.L.; Mann, B.; Chen, M. Analysis of temporal variability in hydrogeochemical data used for multivariate analyses. Groundwater 1993, 31, 221-229. [CrossRef]

35. Suk, H.; Lee, K. Characterization of a groundwater hydrochemical system through multivariate analysis: Clustering into groundwater zones. Groundwater 1999, 37, 358-366. [CrossRef]

36. Lee, J.Y.; Yang, J.S.; Han, M.; Choi, J.Y. Comparison of the microbiological and chemical characterization of harvested rainwater and reservoir water as alternative water resources. Sci. Total Environ. 2010, 408, 896-905. [CrossRef] [PubMed] 
37. Cho, B.W.; Choo, C.O. Geochemical behavior of uranium and radon in groundwater of Jurassic granite area, Icheon, Middle Korea. Water 2019, 11, 1278. [CrossRef]

38. Johnson, R.A.; Wichern, D.W. Applied Multivariate Statistical Analysis, 3rd ed.; Prentice-Hall Inc.: Upper Saddle River, NJ, USA, 1992; ISBN 978-0130417732.

39. Apambire, W.B.; Boyle, D.R.; Michel, F.A. Geochemistry, genesis, and health implications of fluoriferous groundwaters in the upper regions of Ghana. Environ. Geol. 1997, 33, 13-24. [CrossRef]

40. Nordstrom, D.K.; Ball, J.W. Mineral saturation states in natural waters and their sensitivity to thermodynamic and analytical errors. Sci. Geol. Bull. 1989, 42, 269-280. [CrossRef]

41. Busby, J.E.; Plummer, N.; Lee, R.W.; Hanshaw, B.B. Geochemical Evolution of Water in the Madison Aquifer in Parts of Montana, South Dakota, and Wyoming; Professional Report Paper 1273-F; U.S. Geological Survey: Barton Rouge, MS, USA, 1991.

42. Hyun, W.H.; Hwang, J.Y.; Lee, J.Y.; Son, B.S.; Oh, J.H.; Yang, K.H.; Kim, K.H. Mineral composition of the Tamna Formation, Jeju Island, Korea. Jour. Petrol. Soc. Korea. 2016, 25, 335-348. [CrossRef]

43. Jeong, J.O.; Yoon, S.H.; Koh, G.W.; Joe, Y.J.; Hong, J.G.; Kim, J.J. Mineralogical and sedimentological characteristics of the U Formation underlying the volcanic strata in Jeju Island, Korea. J. Geol. Soc. Korea. 2016, 52, 389-403. [CrossRef]

(C) 2020 by the authors. Licensee MDPI, Basel, Switzerland. This article is an open access article distributed under the terms and conditions of the Creative Commons Attribution (CC BY) license (http://creativecommons.org/licenses/by/4.0/). 